\title{
How rural roads benefit the household's asset position: A case study in West Bengal, India
}

\author{
Joyoti Gayen and Debashis Sarkar \\ Department of Agricultural Economics \\ Institute of Agriculture, Visva-Bharati \\ Sriniketan, Birbhum, West Bengal-731236, India \\ E-mail: joyoti_gn@ rediffmail.com \\ sarkaraerc@rediffmail.com
}

\begin{abstract}
An attempt has been made in this study to observe the linkages between rural roads on household assets including material, social and human capital. It has been found that places with better roads and railway systems lead to better asset position of the households and hence an increased livelihood opportunity. The households near main roads and rail stations have a more consistent asset position with lower coefficient of variation (CV) of asset score and having a statistically higher group mean value. Automatically inequality in asset position is more in remote villages. Percentage wise distribution of households according to possession of different household shows the same result. Households adjacent to main road and rail station have higher percentage of consumer durable assets than that of the households who reside away from main road and rail station except possession of different agricultural implements. Other assets position like physical capital consisting of house property status, human capital like educational status, access to health care facilities, sanitation facilities reflect the same picture which indirectly gives a way to a diverse livelihood.
\end{abstract}

Keywords: Rural roads, capabilities, assets position, CV, group mean, diverse livelihoods

\section{Introduction}

Rural roads connectivity is broadly recognised as a fundamental pre-condition for the development of rural areas. Remoteness and lack of mobility are widely identified by the poor themselves as the factors which heighten vulnerability and perpetuate poverty of rural people. Better roads offer an expanded scope of socio-economic opportunity outside village. So, access to physical infrastructure like roads affects rural livelihoods by creating direct or indirect linkages with the determinants of livelihood diversification. As a result of livelihood pattern and its diversification rural families construct a diverse portfolio of activities and social support capabilities in order to survive and improve their standards of living. Constraints like poor asset base including housing assets, land assets, social capital assets, livestock assets, human assets etc. causes a barrier to individuals to expand his portfolio of activities. This study emphasises how rural infrastructure rural roads in particular leads to a changing livelihood pattern in rural economy by improving the asset position. 
Lack of rural infrastructure causes a barrier to livelihood pattern and its diversification. A livelihood comprises the capabilities, assets (including both material and social resources) and activities required for a means of living (Chambers and Conway, 1992). Study made by Escobal and Ponce (2002) on the benefits of rural roads cited that rehabilitated road accessibility enhances non-agricultural income opportunities specially from wage employment sources this income expansion not only increase consumption but the additional income is apparently allocated to savings and also through investments in livestock to combat unfavourable climatic situations (Gannon and Liu, 1997). A livelihood is sustainable when it can cope with and recover from stresses and shocks and maintain or enhance its capabilities and assets both now and in the future, while not undermining the natural resource base (Carney, 1998). Better roads provide greater accessibility to educational, health, employment and market facilities (Lal, 1988). In India this correlation between roads and poverty reduction is ranked at the top of the scale (Singru, 2007). Socio-economic effects of road improvement reveal that the economic benefits and opportunities increase asset value, thus facilitating trade and business opportunities (Singru, 2007). Infrastructure development creates an impact on the human capital and hence on their job opportunities and income prospects. Hence, the key issue is how the development of infrastructure impacts access by the poor (Estache et al., 2000). Reliable transportation system seems particularly important in encouraging parents to allow girls to continue their education and enabling women to participate in social and economic activities outside villages (Cook et al., 2005). Poor asset base is a constraint in livelihood pattern and its diversification (Khatun and Roy, 2012). Increased land assets are linked to agricultural production whereas higher levels of education and greater access to infrastructure appear to be most closely linked to non-agriculture wage employment (Winters et al., 2009). Past studies have shown that socio-economic development of areas considering education, health, family planning, employment, income and other variables are positively correlated with the type and condition of the roads. Areas with poor accessibility were worse off compared to areas with better road access. Greater social and economic progress occurs in areas with paved roads and better connectivity for a longer period of time. In this backdrop an attempt has been made in this study to examine how the rural roads benefit the households especially in augmentation of assets and livelihoods.

\section{Database and Methodology}

The study has been conducted based on both primary and secondary data. Secondary data has been collected from different sources, i.e., Census and Statistical Abstract published by Bureau of Applied Economics and Statistics, Government of West Bengal. The primary data has been collected from two districts. At first, the road density of all districts of West Bengal has 
been calculated based on the secondary data. Then all the districts have been sub-divided into two groups i.e., high and low road density. Howrah district with high road density and Purulia district with low road density have been selected randomly. In the next stage, the list of blocks of the selected districts has been collected and one block from each district namely; Uluberia-I from Howrah and Para from Purulia have been selected randomly. The list of all villages of the selected blocks has been collected and sub-divided into two groups, i.e., (i) proximity to main road and rail station along with presence of paved road and mud road within the villages, and a high population density (ii) away from main road and rail station and which do not have paved road within the village but a high population density. Then two villages from each group i.e., four villages from each district have been selected randomly. In the next stage, the list of the households of the selected villages has been collected and 40 households from each village with a sample of 160 households from each district have been selected. Finally, 320 households have been selected as the ultimate sample unit of the study. The primary data has been collected using structured questionnaires and the data has been analysed by employing descriptive statistics like; tables, percentage, mean, coefficient of variation (CV) and inferential statistics like 'Group mean comparison analyses.

\section{Results and Discussion}

If we divide the dwelling houses into two broad categories viz., households having pucca house in addition to any other type of house semi-pucca/kanchha and the households having temporary houses (Semi-pucca or kanchha houses), it has been observed that majority of the households in both villages (Group 0 and group 1 category according to it vicinity to main road and rail station) have semi-pucca house. The proportion of pucca house was more in those villages those were situated near main roads and railway station both in Howrah and Purulia. This may be due to improve socio-economic conditions which were accentuated for locational advantages. When we combine the households and take the percentage, it shows that the households in Howrah district enjoying its situational advantage and have higher percentages of permanent house than that of Purulia shown in Table-1.

Table-2 shows that how operational land holding differs due to existence of better connectivity. It has been observed that irrespective of districts the size of operational holding is low in villages that are situated near main road and railway station. This may be due to the enhancement of the value of land and can be expressed as positive externality. Average operational holding is low in villages which are situated near main roads and railway station. 
Value of land in these villages was higher and selling of land arisen due to the higher opportunity cost.

An attempt has been made to calculate the asset score of the household due to the existence of road connectivity. Asset score was calculated using several assets like agricultural implements, livestock, durable consumer goods viz., television, cycle, motor cycle, cycle van. If a household has a particular asset, the score will be 1 else 0 . Then we add all scores to get asset score of a particular household. Total asset score then sub-divided into three groups viz., low (score $<3)$, medium (>=3-5) and high $(>=6)$. Based on the $\mathrm{CV}$ and 'group mean comparison method' presented in Table-3 and Table-4 respectively, one can detect how the asset score differs significantly based on the road connectivity. Villages with better connectivity have more consistent asset position.

Table 1: Distribution of households as per type of house

\begin{tabular}{|c|c|c|c|c|c|c|c|c|c|c|c|c|c|}
\hline \multirow[t]{3}{*}{ Type of house } & \multicolumn{4}{|c|}{ Howrah } & \multicolumn{4}{|c|}{ Purulia } & \multirow{2}{*}{\multicolumn{2}{|c|}{$\begin{array}{c}\text { Howrah } \\
\text { Combined }\end{array}$}} & \multirow{2}{*}{\multicolumn{2}{|c|}{$\begin{array}{c}\text { Purulia } \\
\text { Combined }\end{array}$}} & \multirow[t]{3}{*}{ Total } \\
\hline & \multicolumn{2}{|c|}{ Group- 0} & \multicolumn{2}{|c|}{ Group- 1} & \multicolumn{2}{|c|}{ Group- 0} & \multicolumn{2}{|c|}{ Group- 1} & & & & & \\
\hline & No. & $\%$ & No. & $\%$ & No. & $\%$ & No. & $\%$ & No. & $\%$ & No. & $\%$ & \\
\hline Pucca & 23 & \multirow{3}{*}{31.25} & 22 & \multirow{3}{*}{37.50} & 3 & \multirow{3}{*}{10.00} & 17 & \multirow{3}{*}{25.00} & 45 & \multirow{3}{*}{34.38} & 20 & \multirow{3}{*}{17.50} & 65 \\
\hline Pucca+ Semipucca & 2 & & 7 & & 4 & & 3 & & 9 & & 7 & & 16 \\
\hline Pucca + Kanchha & 0 & & 1 & & 1 & & 0 & & 1 & & 1 & & 2 \\
\hline Semipucca & 50 & \multirow{3}{*}{68.75} & 40 & \multirow{3}{*}{62.50} & 41 & \multirow{3}{*}{90.00} & 26 & \multirow{3}{*}{75.00} & 90 & \multirow{3}{*}{65.62} & 67 & \multirow{3}{*}{82.50} & 157 \\
\hline Semipucca+kanchha & 0 & & 3 & & 12 & & 13 & & 3 & & 25 & & 28 \\
\hline Kanchha & 5 & & 7 & & 19 & & 21 & & 12 & & 40 & & 52 \\
\hline $\mathrm{N}$ & 80 & 100.00 & 80 & 100.00 & 80 & 100.00 & 80 & 100.00 & 160 & 100.00 & 160 & 100.00 & 320 \\
\hline
\end{tabular}

Note: Group-0 indicates villages away from main road and rail station, Group-1 indicates villages near main road and rail station

Source: Field survey

Table 2: Size of land holding of the households

\begin{tabular}{|l|c|c|}
\hline \multirow{2}{*}{ Districts } & \multicolumn{2}{|c|}{ Average operational land holding (in ac.) } \\
\cline { 2 - 3 } & Near & Far \\
\hline Howrah & 0.62 & 1.87 \\
\hline Purulia & 2.00 & 2.26 \\
\hline All & 1.31 & 2.06 \\
\hline
\end{tabular}

Source: Field survey

It has been observed in the following Table-4 that the mean value of 'asset score' was 4.88 in case of villages far from main road and railway station and 5.30 in case of villages near main roads and railway station in Howrah district. By employing t-test, it has been observed that the ' $p$ ' value has been observed to be of 0.065 with degree of freedom of 158 . The two group mean for asset score of the household under study significantly differs at 10 per cent level of significance. Similarly, it has been observed that the mean value for 'asset score' was 4.75 in 
case of villages far from main road and railway station and 5.36 in case of villages near main roads and railway station in Purulia. By employing t-test, it has been observed that the ' $p$ ' value was 0.006 with 158 degree of freedom. The two group mean for asset score of the household under study significantly differs at 1 per cent level of significance. Irrespective of districts, the mean value of two groups for 'asset score' was 4.81 in case of villages far and 5.33 in case of villages near to main roads and railway station. By employing t-test, it has been observed that the 'p' value was 0.001 with 318 of degree of freedom and the two group mean for asset score of the household under study significantly differs at 1 per cent level of significance. Consequently, it can be concluded that the asset position of the households located near main road and rail station was better than those which were situated far from main roads and rail station which leads to a more diversified livelihood pattern which were statistically significant too.

\section{Table 3: Coefficient of Variation (CV) of asset score}

\begin{tabular}{|l|c|c|}
\hline Particulars & N & CV \\
\hline \multicolumn{3}{|c|}{ Howrah } \\
\hline Group 0 & 80 & 31.18 \\
\hline Group 1 & 80 & 25.72 \\
\hline \multicolumn{3}{|c|}{ Purulia } \\
\hline Group 0 & 80 & 27.52 \\
\hline Group 1 & 80 & 27.19 \\
\hline \multicolumn{3}{|c|}{ All } \\
\hline Group 0 & 80 & 29.42 \\
\hline Group 1 & 80 & 26.27 \\
\hline
\end{tabular}

Note: Group 0- Villages far from main road and rail station, Group 1 -Villages near main road and rail station; Source: Field survey

\section{Table 4: Group statistics of asset score}

\begin{tabular}{|c|c|c|c|c|c|c|c|}
\hline \multirow[t]{2}{*}{ District } & \multirow{2}{*}{$\begin{array}{l}\text { Type of } \\
\text { group }\end{array}$} & \multicolumn{3}{|c|}{ Group statistics } & \multicolumn{3}{|c|}{ t-test for equality of means } \\
\hline & & $\mathrm{N}$ & Mean & $\mathrm{SD}$ & $\mathrm{t}$ & Sig. (2 tailed) & Level of significance \\
\hline \multirow[t]{2}{*}{ Howrah } & 0 & 80 & 4.88 & 1.52 & \multirow[t]{2}{*}{-1.861} & \multirow[t]{2}{*}{0.065} & \multirow[t]{2}{*}{$10 \%$} \\
\hline & 1 & 80 & 5.30 & 1.36 & & & \\
\hline \multirow[t]{2}{*}{ Purulia } & 0 & 80 & 4.75 & 1.31 & \multirow[t]{2}{*}{-2.795} & \multirow[t]{2}{*}{0.006} & \multirow[t]{2}{*}{$1 \%$} \\
\hline & 1 & 80 & 5.36 & 1.46 & & & \\
\hline \multirow[t]{2}{*}{ All } & 0 & 160 & 4.81 & 1.42 & \multirow[t]{2}{*}{-3.287} & \multirow[t]{2}{*}{0.001} & \multirow[t]{2}{*}{$1 \%$} \\
\hline & 1 & 160 & 5.33 & 1.41 & & & \\
\hline
\end{tabular}

Note: Group 0- Villages far from main road and rail station, Group 1 -Villages near to main road and rail station; Source: Field survey

Therefore, the better transportation system gives way to less variation in assets among the people. The households adjacent to main road and rail station have higher consumer assets than those who reside far from main road and rail station. Percentage distribution of livestock also gave a hint of better investment in livestock and cattle in places with better road connectivity 
(Table- 5). It has been found that households residing comparatively away from main road and rail station depend mostly on agricultural activities and therefore retains more agricultural implements. Households adjacent to main road and rail station with better connectivity depend mostly on non-farm activity.

Table 5: Distribution of households according to possession of farm implements

\begin{tabular}{|c|c|c|c|c|}
\hline \multirow[t]{3}{*}{ Types of machinery and implements } & \multicolumn{4}{|c|}{ Distribution of households according to possession of farm implements } \\
\hline & \multicolumn{2}{|c|}{ Howrah } & \multicolumn{2}{|c|}{ Purulia } \\
\hline & No. & $\%$ & No. & $\%$ \\
\hline \multicolumn{5}{|c|}{ Villages near main road and rail station } \\
\hline Tractor & 0 & 0.00 & 3 & 3.75 \\
\hline Harvester & 1 & 1.25 & 5 & 6.25 \\
\hline Rice thrasher & 13 & 16.25 & 16 & 20.00 \\
\hline Pump machine & 6 & 8.00 & 21 & 26.25 \\
\hline Other minor machines & 28 & 35.00 & 61 & 76.25 \\
\hline \multicolumn{5}{|c|}{ Villages far from main road and rail station } \\
\hline Tractor & 3 & 4.00 & 6 & 7.50 \\
\hline Harvester & 4 & 5.00 & 5 & 6.25 \\
\hline Rice thrasher & 22 & 27.50 & 20 & 25.00 \\
\hline Pump machine & 14 & 17.50 & 18 & 22.50 \\
\hline Other minor machines & 64 & 80.00 & 74 & 93.00 \\
\hline & \multicolumn{2}{|c|}{ All (Near main road and rail station) } & \multicolumn{2}{|c|}{ All (far from main road and rail station) } \\
\hline Tractor & 3 & 1.88 & 9 & 5.63 \\
\hline Harvester & 6 & 3.75 & 9 & 5.63 \\
\hline Rice thrasher & 29 & 18.13 & 42 & 26.25 \\
\hline Pump machine & 27 & 16.88 & 32 & 20.00 \\
\hline Other minor machines & 89 & 55.63 & 138 & 86.25 \\
\hline
\end{tabular}

Source: Field survey

Education is human capital which is an important asset for livelihood changes. Tables- 6 and 7 along with the graphical presentation in Fig.1 show how improved access to road was linked to higher levels of education. It has been found that irrespective of district the households have better educational status those who were near to main road and rail station. It can be tinted that high road density influenced the educational level. Howrah was better placed than Purulia in terms of level of education because of the higher road density in general and better communication system in particular. The percentage of population in the category of graduate $\&$ above is higher in both the districts due to proximity to main road \& rail station. It has been found that the number of students availing higher secondary schools, colleges and other technical/diploma institutions were higher in those villages those were situated near main road and rail connectivity. Figure-1 depicts that 58.14 per cent of the respondents who reside near main road and rail station have achieved middle school level of education. On the contrary 57.5 per cent of the respondents have acquired educational qualification up to the primary level who resides away from road. 
Table 6: Level of education of the respondents

\begin{tabular}{|l|c|c|c|c|c|c|}
\hline \multirow{2}{*}{ Level of Education } & \multicolumn{2}{|c|}{ Howrah } & \multicolumn{2}{c|}{ Purulia } & \multicolumn{2}{c|}{ All } \\
\cline { 2 - 8 } & $\begin{array}{c}\text { Proximity to } \\
\text { main road \& } \\
\text { rail station }\end{array}$ & $\begin{array}{c}\text { Away from } \\
\text { main road \& } \\
\text { rail station }\end{array}$ & $\begin{array}{c}\text { Proximity to } \\
\text { main road \& } \\
\text { rail station }\end{array}$ & $\begin{array}{c}\text { Away from } \\
\text { main road \& } \\
\text { rail station }\end{array}$ & $\begin{array}{c}\text { Proximity to } \\
\text { main road \& } \\
\text { rail station }\end{array}$ & $\begin{array}{c}\text { Away from } \\
\text { main road \& } \\
\text { rail station }\end{array}$ \\
\hline Illiterate & 6.25 & 10.00 & 20.00 & 30.00 & 13.13 & 20.00 \\
\hline Just Literate & 15.00 & 11.25 & 12.50 & 1.25 & 13.75 & 6.25 \\
\hline Up to Primary & 16.25 & 41.25 & 13.75 & 21.25 & 15.00 & 31.25 \\
\hline Up to middle school & 26.25 & 15.00 & 23.75 & 25.00 & 25.00 & 20.00 \\
\hline Secondary & 18.75 & 11.25 & 17.50 & 13.75 & 18.13 & 12.50 \\
\hline Higher Secondary & 10.00 & 6.25 & 8.75 & 5.00 & 9.38 & 5.63 \\
\hline Graduate \& above & 7.50 & 3.75 & 3.75 & 2.50 & 5.63 & 3.13 \\
\hline Technical/Diploma & - & 1.25 & -- & 1.25 & - & 1.25 \\
\hline
\end{tabular}

Source: Field survey

Table 7: Members attending higher secondary schools/colleges/technical institutions

\begin{tabular}{|l|c|c|c|c|c|c|}
\hline \multirow{3}{*}{ Gender } & \multicolumn{4}{|c|}{ Members attending higher secondary schools/colleges/technical institutions } \\
\cline { 2 - 7 } & $\begin{array}{c}\text { Howrah } \\
\text { Villages near } \\
\text { to main road \& } \\
\text { rail station }\end{array}$ & $\begin{array}{c}\text { Villages away } \\
\text { from main road } \\
\& \text { rail station }\end{array}$ & $\begin{array}{c}\text { Villages near } \\
\text { to main road \& } \\
\text { rail station }\end{array}$ & $\begin{array}{c}\text { Villages away } \\
\text { from main road } \\
\& \text { rail station }\end{array}$ & $\begin{array}{c}\text { Villages near } \\
\text { to main road \& } \\
\text { rail station }\end{array}$ & $\begin{array}{c}\text { Villages away } \\
\text { from main road } \\
\& \text { rail station }\end{array}$ \\
\hline Male & 25 & 20 & 17 & 9 & 42 & 29 \\
\hline Female & 15 & 11 & 10 & 5 & 25 & 6 \\
\hline Total & 40 & 31 & 27 & 14 & 67 & 45 \\
\hline
\end{tabular}

Source: Field survey

Figure 1: Level of education of the respondents

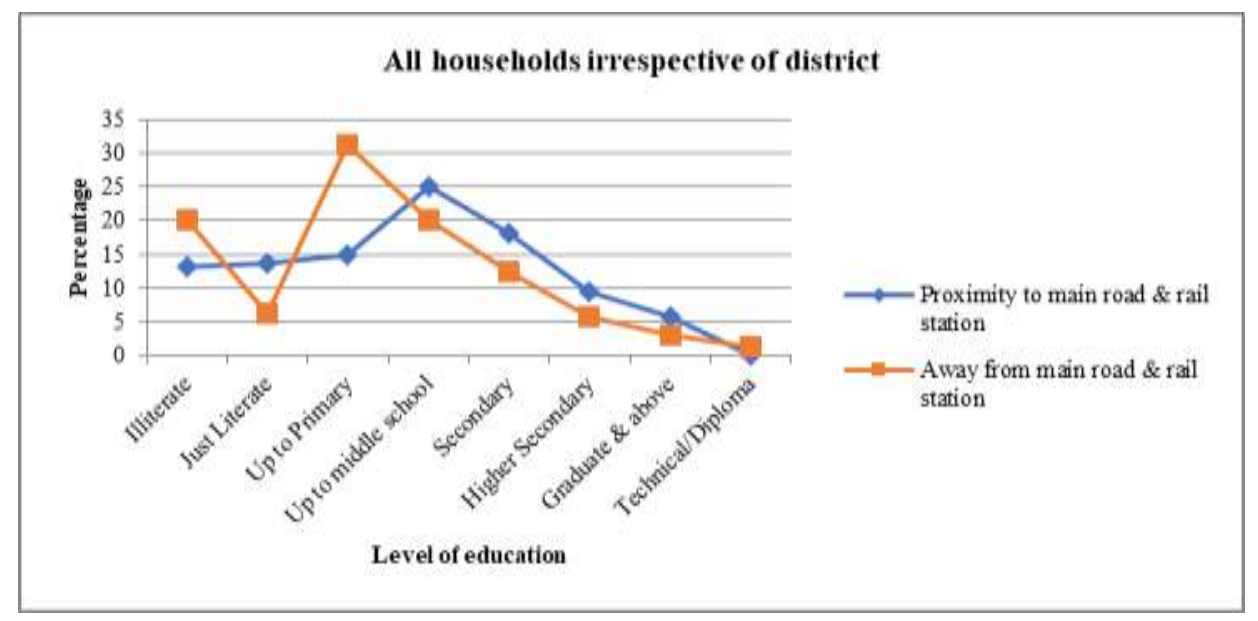

Improvement in rural infrastructure fosters financial capital asset which is reflected in the credit facilities of the households. Saha et al. (2011) observed that diversifiers were significantly different from non-diversifiers on availability of financial assets (access to credit) and extent to local infrastructure. Table- 8 shows that the number of households availing credit facilities is little more in those villages which are situated away from main roads. However, it has been 
found that 51.92 per cent of households reside near main roads and rail station have access to institutional sources, whereas majority of the households reside away from main roads borrow from non-institutional sources. Table- 9 presents a clear picture about the accessibility which leads to higher credibility. If one can look at both the districts together, it has been found that the amount of loans taken from various sources is higher in the villages away from roads. This situation arises due to the absence of accessibility to institutional sources which force the households to borrow from village money lenders.

Table 8: Distribution of households according to availing different sources of credit

\begin{tabular}{|c|c|c|c|c|}
\hline \multirow[t]{2}{*}{ Source of Credit } & \multicolumn{2}{|c|}{ Howrah } & \multicolumn{2}{|c|}{ Purulia } \\
\hline & No. & $\%$ & No. & $\%$ \\
\hline \multicolumn{5}{|c|}{ Villages near main road and rail station } \\
\hline Institutional source & 12 & 52.17 & 15 & 51.72 \\
\hline Non-Institutional source & 0 & 0 & 0 & 0 \\
\hline SHG & 10 & 43.48 & 13 & 44.83 \\
\hline Both (SHG+ML) & 1 & 1.25 & 1 & 3.45 \\
\hline $\mathrm{N}$ & 23 & 100 & 29 & 100 \\
\hline \multicolumn{5}{|c|}{ Villages away from main road and rail station } \\
\hline Institutional source & 10 & 28.57 & 7 & 35 \\
\hline Non-Institutional source & 13 & 36.11 & 10 & 50 \\
\hline SHG & 11 & 30.56 & 0 & 0 \\
\hline Both (SHG+ML) & 1 & 2.78 & 3 & 15 \\
\hline $\mathrm{N}$ & 35 & 100 & 20 & 100 \\
\hline & \multicolumn{2}{|c|}{ All (near main road and rail station } & \multicolumn{2}{|c|}{ All (Away from main road and rail station) } \\
\hline Institutional source & 27 & 51.92 & 17 & 30.91 \\
\hline Non-Institutional source & 0 & 0 & 23 & 41.82 \\
\hline SHG & 23 & 44.23 & 11 & 20 \\
\hline Both (SHG+ML) & 2 & 3.85 & 4 & 7.27 \\
\hline $\mathrm{N}$ & 52 & 100 & 55 & 100 \\
\hline
\end{tabular}

Source: Field survey

Table 9: Amount of loans disbursed from different institutional/non-institutional sources

\begin{tabular}{|c|c|c|c|c|}
\hline \multirow[t]{2}{*}{ Sources of credit } & Howrah & Purulia & Howrah & Purulia \\
\hline & \multicolumn{2}{|c|}{$\begin{array}{c}\text { Villages near main road and railway } \\
\text { station }\end{array}$} & \multicolumn{2}{|c|}{$\begin{array}{c}\text { Villages away from main road and railway } \\
\text { station }\end{array}$} \\
\hline Institutional source & $5,75,000$ & $5,96,000$ & $5,05,000$ & $4,70,000$ \\
\hline Non-Institutional source & 0 & 0 & $3,45,000$ & $1,75,000$ \\
\hline SHG & $1,12,000$ & $1,08,000$ & $1,65,000$ & 0 \\
\hline Both (SHG+ML)/(BANK+SHG) & $1,20,000$ & 45000 & 45000 & 85,000 \\
\hline $\mathrm{N}$ & $8,07,000$ & $7,49,000$ & $10,60,000$ & $7,30,000$ \\
\hline \multicolumn{5}{|c|}{ All } \\
\hline Institutional source & \multicolumn{2}{|c|}{$11,71,000$} & \multicolumn{2}{|c|}{$9,75,000$} \\
\hline Non-Institutional source & \multicolumn{2}{|c|}{0} & \multicolumn{2}{|c|}{$5,20,000$} \\
\hline SHG & \multicolumn{2}{|c|}{$2,20,000$} & \multicolumn{2}{|c|}{$1,65,000$} \\
\hline Both $(\mathrm{SHG}+\mathrm{ML}) /(\mathrm{BANK}+\mathrm{SHG})$ & \multicolumn{2}{|c|}{$1,65,000$} & \multicolumn{2}{|c|}{$1,30,000$} \\
\hline $\mathrm{N}$ & \multicolumn{2}{|c|}{$15,56,000$} & \multicolumn{2}{|c|}{$17,90,000$} \\
\hline
\end{tabular}

Source: Field Survey 
Various studies have documented that rural infrastructure raises the travel frequency of households and thereby increases the accessibility and bringing the distant close together. While comparison between diversifier and non-diversifier on different livelihood assets, Saha et al. (2011) observed that the former differed significantly from the later in family education status, contact with personal localite and awareness about diversification due to mobility. Thus, rural roads results in socio-economic development by influencing the social variables like access to markets, raising enormously social mobility, political participation. Table- 10 presents the mobility of the households and it can be pragmatic that how the percentage distribution of the households differs according to the number of visits to various places outside Gram Panchayat (GP). It is clearly seen that the members of households reside near main road/rail station use to visit to the town/city/district head quarter/market very often than those households who reside at relatively poorly connected villages.

\section{Table 10: Status of mobility of the households}

\begin{tabular}{|l|c|c|c|c|c|c|}
\hline \multirow{2}{*}{$\begin{array}{l}\text { Average number of times } \\
\text { visiting outside GP/ month }\end{array}$} & \multicolumn{4}{|c|}{ Percentage of households visiting outside } \\
\cline { 2 - 8 } & \multicolumn{2}{|c|}{ Howrah } & Purulia & \multicolumn{3}{c|}{ All } \\
\cline { 2 - 8 } & Near road & Away road & Near road & Away road & Near road & Away road \\
\hline $0-4$ & 27.50 & 47.50 & 31.25 & 55.00 & 29.38 & 51.25 \\
\hline $4-8$ & 35.00 & 30.00 & 52.50 & 25.00 & 43.75 & 27.50 \\
\hline $8-12$ & 17.50 & 16.25 & 7.50 & 13.75 & 12.50 & 15.00 \\
\hline 12 and above & 20.00 & 6.25 & 8.75 & 6.25 & 14.37 & 6.25 \\
\hline Total & 100.00 & 100.00 & 100.00 & 100.00 & 100.00 & 100.00 \\
\hline
\end{tabular}

Source: Field Survey

Table 11: Group statistics for social participation score

\begin{tabular}{|c|c|c|c|c|c|c|c|}
\hline \multirow[b]{2}{*}{ District } & \multirow{2}{*}{$\begin{array}{l}\text { Type of } \\
\text { Group }\end{array}$} & \multicolumn{3}{|c|}{ Group Statistics } & \multicolumn{3}{|c|}{ t- Test for Equality of Means } \\
\hline & & $\mathrm{N}$ & Mean & $\mathrm{SD}$ & $\mathrm{T}$ & Sig. (2 tailed) & Level of significance \\
\hline \multirow[t]{2}{*}{ Howrah } & 0 & 80 & 0.43 & 0.50 & \multirow[t]{2}{*}{-2.74} & \multirow[t]{2}{*}{0.007} & \multirow[t]{2}{*}{$1 \%$} \\
\hline & 1 & 80 & 0.64 & 0.48 & & & \\
\hline \multirow[t]{2}{*}{ Purulia } & 0 & 80 & 0.65 & 0.49 & \multirow[t]{2}{*}{-0.493} & \multirow[t]{2}{*}{0.623} & \multirow[t]{2}{*}{$>10 \%$ (insignificant) } \\
\hline & 1 & 80 & 0.77 & 0.48 & & & \\
\hline \multirow[t]{2}{*}{ All } & 0 & 160 & 0.53 & 0.50 & \multirow[t]{2}{*}{-2.282} & \multirow[t]{2}{*}{0.023} & \multirow[t]{2}{*}{$5 \%$} \\
\hline & 1 & 160 & 0.65 & 0.48 & & & \\
\hline
\end{tabular}

Note: Equal variances assumed; Group 0- Villages far from main road and rail station, Group 1 -Villages near main road and rail station; Source: Field survey

Social participation of the people enhances due to increase in mobility. The social participation can be captured through 'social participation score (SP)'. However, in this case the SP of the members of the household has been categorized by 0 or 1 according to their participation in meetings of Gram Panchayat, Police Station, Zilla Parishad, MLA/MP, others (SHG). and has been tested statistically by group mean comparison method. Whether any 
significant difference exist in the mean values among two groups of households in regard to social participation score in these districts has been observed from t-test for equality of means. Finally, the same test has been carried out taking all the households irrespective of district only sub-grouping them according to their vicinity to main road and rail station and the result of the analysis is presented in Table- 11.

Based on the fact in Table- 11 it is factual that social participation of the households becomes higher with improvement in communication. If we study the last row where all the households have been studied together irrespective of district, we find that mean value of two groups for "Social Participation" of the households under study was 0.53 in case of villages far from main road and railway station and 0.65 in case of villages near main roads and railway station. The result shows that the significance value is 0.023 and degrees of freedom was 318 . So, the two group mean for "Social participation score" of the household under study significantly differs at 5 per cent level of significance. This holds true for both districts. From the above tabular and inferential analysis, it can be inferred that social participation of the household also rises due to increase in mobility. This may help the rural people in social capital formation which is considered as one of the important livelihood assets.

\section{Conclusion}

The study has proved that lack of rural infrastructure causes a barrier to livelihood pattern and its diversification. Improved roads accessibility enhances non-agricultural income opportunities especially from wage employment. Accordingly, the income expansion not only increases consumption but the additional income is apparently allocated to savings and also through investments in livestock to combat unfavourable climatic situations. Thus, improvement in connectivity through roads is unmistakably serious concern which was further substantiated through the foregoing analyses and discussion. It has been found that improvement in communication influenced the asset score along with social participation score of an individual. It has been observed that the households have better educational status those who were near to main road and rail station. It can be tinted that high road density influences the educational level too. Thus, it can be anecdotal that physical infrastructure like rural roads bear a close linkage with asset base of the rural masses which was an important determinant for livelihood and its diversification in study areas. 


\section{References}

Carney, D (1998). Implementing the sustainable rural livelihoods approach. Chapter 1 in D. Carney, editor. Sustainable rural livelihoods: What contribution can we make? Department for International Development, London, UK.

Chambers, R and Conway, G. (1992). Sustainable Rural Livelihoods: Practical concepts for the $21^{\text {st }}$ Century. IDS Discussion paper 296, IDS, Brighton.

Cook, C., Duncan, T., Jitsuchon, S., Sharma, A. and Guobao, W. (2005). Assessing the Impact of Transport and Energy Infrastructure on Poverty Reduction, Asian Development Bank. Manila.

Escobal Javier; Ponce, Carmen. (2002). The Benefits of Rural Roads: Enhancing Income opportunities for the Rural Poor, GRADE's working paper. 40-I

Estache, A., Goimez-Lobo, A. \& Leipziger, D. (2000). Utility privatization and the needs of the poor in Latin America. Have we learnt enough to get it right? Infrastructure for development: private solutions and the poor, 31 May - 2 June: London, U.K.

Gannon, C, \& Lui, Z. (1997). Poverty and transport. Washington, DC. The World Bank INU/TWU Series Transport Publications. TWU-30.

Khatun, Dilruba and Roy, B.C. (2012). Rural Livelihood Diversification in West Bengal: Determinants and constraints, Agricultural Economics Research Review,25(1): pp. 115124.

Lal, M. (1988). Impact of road improvement in a Chotanagpur village, Tradition-anddevelopment; pp. 255-263.

Saha, Biswarup and Bahal, Ram. (2011). Analysis of Diversifier and non-diversifier Farm households in West Bengal. Indian Research Journal for Extension and Education.11(2).

Singru, N. (2007). Socioeconomic effects of Road Improvements, From the 2007 Sector Assistance Program Evaluation for the Transport Sector in India - Focusing on results, Operations Evaluation Department, Asian Development Bank.

Winters, Paul; Davis, Benjamin; Carletto, Gero; Covarrubias; Quinones, Esteban J.; Zezza Alberto; Azzarri Carlo and Stamoulis Kostas. (2009). Assets, Activities and Rural Income Generation: Evidence from a Multicountry Analysis. Food and Agriculture Organisation, Rome, Italy. World Development. Vol. 37, No.9, pp.-1435 -1452. 